\title{
Changes on Total Serum Bilirubin and Infant's Position during Phototherapy
}

\author{
Ira Silvia*, Guslihan Dasa Tjipta, Lily Irsa, Emil Azlin, Bugis Mardina Lubis, Oke Rina \\ Ramayani \\ Department of Child Health, Medical school, Faculty of Medicine, University of Sumatera Utara, Haji Adam \\ Malik Hospital, Medan, Indonesia
}

*Corresponding Author: Dr. Ira Silvia, Department of Child Health, Medical School, University of Sumatera Utara / H. Adam Malik Hospital, Medan, Indonesia, Email: irasilvia322@ gmail.com

\begin{abstract}
Background: Hyperbilirubinemia is a problem that occur during neonate. In management of neonatal hyperbilirubinemia, phototherapy is a method to decrease total serum bilirubin (TSB). During phototherapy, changing position of neonates every 3 hours may reduced TSB rapidly.
\end{abstract}

Objectives: To analyze the reduction of TSB during conventional phototherapy in supine position exclusively versus alternated position every 3 hours.

Methods: A randomized controlled study was conducted in July to October 2012 in neonatology unit Adam Malik and Pirngadi General Hospital Medan, North Sumatera, Indonesia. Sample was selected i.e physiological neonatal hyperbilirubinemia, with gestational age between $\geq 32$ to $\leq 42$ weeks. At the beginning of phototherapy, TSB was measured and also after 24 hours phototherapy. The analysis used dependent t-test.

Results: A total 76 neonates were included in this study. In each group, TSB level of 38 neonatal decreased after 24 hours of phototherapy $(3.8 \mathrm{mg} / \mathrm{dL})$ in group with position changes every 3 hours mean while 3.7 $m g / d L$ in supine position $(P=0.751)$.

Conclusion: There was no significant difference in the decrease in TSB levels between the groups alternating position every 3 hours and the supine position

Keywords: hyperbilirubinemia, neonates, phototerapy, position

\section{INTRODUCTION}

Hyperbilirubinemia is an increase of bilirubin level in plasma by 2 standard deviations or above the 90th percentile of expected value of an infant age. ${ }^{1}$ This is the most common in newborns, ${ }^{2,3}$ clinically manifests when serum bilirubin levels increases more than 5 to 7 $\mathrm{mg} / \mathrm{dl},{ }^{1}$ with a quite high incidence rate, especially in premature infants and often occurs in the first week of life. ${ }^{4}$

Phototherapy is a physically apparent therapy using light as a treatment for hiperbilirubinemia. ${ }^{5}$ This treatment goal is to limit the increase bilirubin and to prevent it to become serious permanent neurological complications (Kern icterus). ${ }^{6}$ The effect of phototherapy is associated with higher levels of bilirubin in the skin and light intensity. The light intensity itself is influenced by the distance between light and skin, body surface area, the type and wavelength of light. ${ }^{5,6}$ Changing position may improve the effectiveness in reducing TSB and shorten duration of this therapy. The evidence supporting this practice of changing position is still limited.

\section{METHODS}

A randomized controlled trial study was conducted at Unit Neonatology H. Adam Malik and Pirngadi General Hospital from July 2012 to October 2012. Inclusion criteria were hyperbilirubinemia in infants with 32 to 42 weeks, birth age of 24 hours to 7 days, and meet the indications for phototherapy. Exclusion criteria were infants with the indication of exchange transfusion, hemolytic disease, and congenital anomaly.

Considerations for phototherapy was done based on TSB that are customized according to age (hours) and body weight as recommended by AAP for infants with hyperbilirubinemia. 
Subjects allocation were performed with simple randomized using sealed envelopes. Before phototherapy, routine blood tests, total serum bilirubin, bilirubin direct, Coomb test and reticulocyte count were performed.

Phototherapy was given by using standard phototherapy unit branded Tessna contained 5 pieces of parallel positioned blue light lamp (Toshiba brand 20WT52). The treatment was given continuously, except while feeding and nursing in the last 30 minutes of every 3 hours. Infants were placed naked in their bed except for a diaper and eye protection. Infants were treated with the lights at a distance of $20 \mathrm{~cm}$ between infants and lamps.

Both groups were given additional fluids as much as $10 \%$ of the total fluid demand both orally or intravenously. Measurement of TSB level was performed after 24 hours. Examination of the intensity of blue light was performed by using a Radiometer branded Dale 40 produced in 2008. Discontinued of phototherapy was done if TSB levels reached normal limit in accordance with AAP criteria or found any side effects. Measurement of body temperature was done in the armpit of every infant.

Ethics Committee of the Faculty of Medicine, University of Sumatera Utara was approved this study. For parents of infants were obtained verbal and written informed consent.

\section{STATISTICAL ANALYSIS}

Data were processed using a computerized program with CI 95\% and level of significance $\mathrm{P}<0.05$. To see the difference of reduction in TSB levels between two groups, was used tindependent test. To see the difference of TSB levels before and after treatment, was used tdependent test..

\section{ReSUlts}

There were 89 neonates who suffered neonatal hyperbilirubinemia and 9 were excluded (4 infants had hyperbilirubinemia direct, 3 infants suffered from congenital anomaly and 2 infant refused ). Eighty infants fulfilled the inclusion and exclusion criteria, from which four did not complete the study ( 2 infants were taken home before the treatment was completed, and 2 others did not have complete medical record due to the parent's unwillingness about invasive procedure of blood sampling). Achievable population were 76 infants. From both units, 52 infants $(68 \%)$ were admitted to $\mathrm{H}$. Adam Malik General Hospital and 24 other (32\%) were admitted to Pirngadi General Hospital. All subjects were divided as infants with alternated positions and supine only positions. Every 3 hours, infants from the first group were positionally alternated supine to prone position and viceversa. (figure 1)

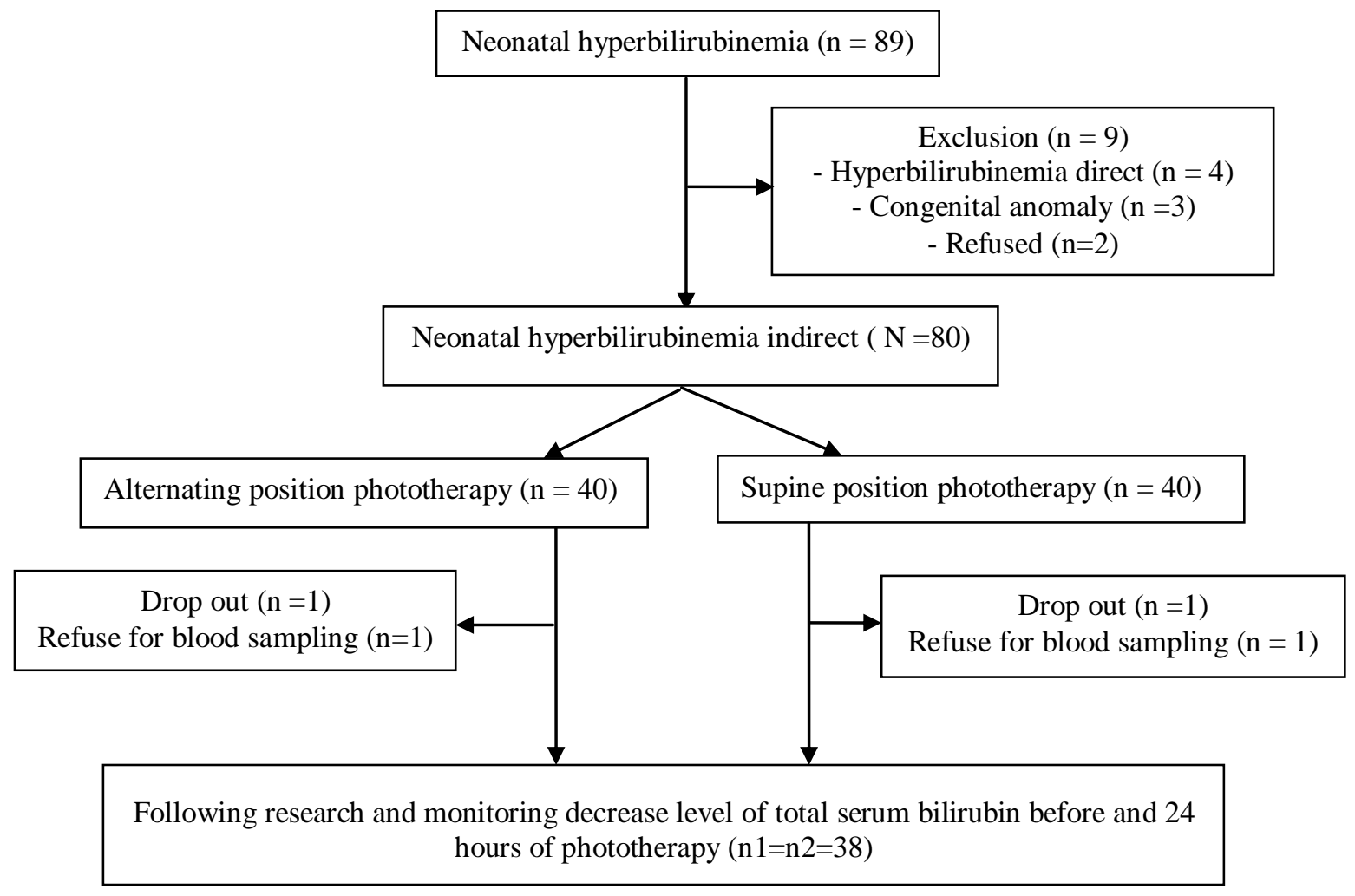

Figure1. Study flow chart 
Table1. Baseline characteristics in the study

\begin{tabular}{|c|c|c|c|c|}
\hline \multirow[t]{2}{*}{ Characteristics } & \multicolumn{4}{|c|}{ Position } \\
\hline & \multicolumn{2}{|c|}{$\begin{array}{c}\text { Alternating } \\
(\mathbf{n}=\mathbf{3 8})\end{array}$} & \multicolumn{2}{|c|}{$\begin{array}{c}\text { Supine } \\
(\mathbf{n = 3 8})\end{array}$} \\
\hline Day care (days), mean (SD) & 5.0 & $(1.39)$ & 5.0 & $(1.20)$ \\
\hline Gender, n (\%): & & & & \\
\hline - Male & 15 & $(39.5)$ & 20 & $(52.6)$ \\
\hline - Female & 23 & $(60.5)$ & 18 & $(47.4)$ \\
\hline Birth weight ' & 2810.5 & $(660.42)$ & 2509.1 & $(57.02)$ \\
\hline Gestational age, $\mathrm{n}(\%)$ & & & & \\
\hline - $34-36$ weeks & 16 & $(42.1)$ & 27 & $(71.0)$ \\
\hline - $37-39$ weeks & 18 & $(47.4)$ & 8 & $(21.0)$ \\
\hline - $40-42$ weeks & 4 & $(10.5)$ & 3 & $(8.0)$ \\
\hline Temperature $\left({ }^{0} \mathrm{C}\right)$, mean $(\mathrm{SD})$ & 36.9 & $(0.92)$ & 36.9 & $(0.29)$ \\
\hline Feeding during, n (\%) & & & & \\
\hline - Breast milk & 11 & $(29.0)$ & 12 & $(31.6)$ \\
\hline - Formula & 6 & $(15.8)$ & 10 & $(26.3)$ \\
\hline - Breast milk and formula & 21 & $(55.2)$ & 16 & $(42.1)$ \\
\hline Haemoglobin & 14.3 & $(3.43)$ & 15.3 & $(3.80)$ \\
\hline Hematocrite & 37.8 & $(8.53)$ & 36.9 & $(8.96)$ \\
\hline Leucocyte & 11.8 & $(5.44)$ & 12.4 & $(5.95)$ \\
\hline Trombocyte & 170105.3 & $(50123.00)$ & 187084.1 & $(52559.75)$ \\
\hline Reticulocyte & 1.9 & $(0.65)$ & 2.1 & $(0.29)$ \\
\hline Albumine & 2.7 & $(0.16)$ & 2.7 & $(0.18)$ \\
\hline CRP, n (\%): & & & & \\
\hline - Positive & 0 & $(0)$ & 0 & $(0)$ \\
\hline - Negative & 38 & $(100)$ & 38 & $(100)$ \\
\hline Coomb test, $\mathrm{n}(\%)$ : & & & & \\
\hline - Positive & 0 & $(0)$ & 0 & $(0)$ \\
\hline - Negative & 38 & $(100)$ & 38 & $(100)$ \\
\hline Light irradiance $\left(\mu \mathrm{W} / \mathrm{cm}^{2} / \mathrm{nm}\right)$ & 8.5 & $(0.50)$ & 8.4 & $(0.55)$ \\
\hline
\end{tabular}

Baseline characteristic feature of infants in both alternating and supine only groups can be seen in table 1. Assessment includes day care, gender, birth weight, gestational age, body temperature, feeding, hemoglobin, hematocrit, leucocytes, platelets, reticulocyte, CRP,Coomb test and light irradiance.

Table2. Total serum bilirubin level in alternating and supine position group before and after 24 hours phototherapy

\begin{tabular}{|c|c|c|c|}
\hline Position & $\begin{array}{c}\text { Before } \\
\text { phototherapy }\end{array}$ & $\begin{array}{l}\text { After } 24 \text { hours } \\
\text { phototherapy }\end{array}$ & $\begin{array}{c}\mathbf{P} \\
(95 \% \mathrm{CI})\end{array}$ \\
\hline Alternating : & & & \\
\hline Total serum bilirubin (mg/dL), mean (SD) & 14.6 (3.24) & $10.8(3.38)$ & $0.0001(3.969 ; 4.587)$ \\
\hline Direct bilirubin & $0.6 \quad(0.24)$ & $0.4 \quad(0.21)$ & $0.0001(0.163 ; 0.249)$ \\
\hline Supine : & & & \\
\hline Total serum bilirubin & $16.1 \quad(2.37)$ & $12.4(2.44)$ & $0.0001(3.320 ; 4.122)$ \\
\hline Direct bilirubin & $0.6 \quad(0.24)$ & $0.4 \quad(0.20)$ & $0.0001(0.138 ; 0.296)$ \\
\hline
\end{tabular}

At the initial examination of the total serum groups was found significant.

bilirubin levels, the difference between the

Table3. Reduction of total serum bilirubin level in two groups after 24 hours phototherapy

\begin{tabular}{|l|l|l|l|}
\hline & \multicolumn{3}{|c|}{ Position } \\
\hline $\begin{array}{l}\text { Total serum bilirubin } \\
\text { decreasing }\end{array}$ & \multicolumn{1}{|c|}{$\begin{array}{c}\text { Alternating } \\
(\mathbf{n = 3 8})\end{array}$} & \multicolumn{1}{|c|}{$\begin{array}{c}\text { Supine } \\
(\mathbf{n = 3 8})\end{array}$} \\
\hline $\begin{array}{l}\text { Serum bilirubin (mg/dL), } \\
\text { mean (SD) }\end{array}$ & $3.8(2.42)$ & $3.7(1.23)$ & $0.751 \quad(1.086 ; 0.789)$ \\
\hline $\begin{array}{l}\text { Direct bilirubin (mg/dL), } \\
\text { mean(SD) }\end{array}$ & $0.2(0.15)$ & $0.2(0.15)$ & $0.278 \quad(0.121 ; 0.036)$ \\
\hline
\end{tabular}

Table 3 shows that reducing TSB levels no significant differences

between alternating and supine position found 


\section{DISCUSSION}

Hyperbilirubinemia is one of the problems that often are found in new born baby. ${ }^{7}$ The assessment of baseline characteristics in both groups from this study includes gender, birth weight, gestational age, body temperature, feeding, hemoglobin, hematocrit, leucocytes, platelets, reticulocyte, CRP, Coomb tests, and light irradiance. The average age of neonatal phototherapy began at age 4 to 5 days, this is related to an increase in bilirubin levels peak at age 3 to 5 days. $^{8}$

We found that the level of albumin in both groups was $2.7 \mathrm{mg} / \mathrm{dL}$. Albumin functioned as a carrier for indirect bilirubin to be conjugated in the liver for further degradation process. ${ }^{8,9}$ Albumin bound bilirubin is a dianion form. Every $1 \mathrm{~g}$ of albumin has a capacity to bind able to bind bilirubin as much as $8.3 \mathrm{mg}$, infants with the level of albumin as much as 3.0 to $3.5 \mathrm{~g} / \mathrm{dL}$ should be able to bind bilirubin as much as 25 to $28 \mathrm{mg} / \mathrm{dL}$ (428 to $479 \mu \mathrm{mol} / \mathrm{L}){ }^{9,10}$ A clinical trial research in Iran showed that infusion of albumin $20 \%$ of $1 \mathrm{~g} / \mathrm{kg}$ body weight in term neonates who had hyperbilirubinemia and exchange transfusion thereafter could lower indirect bilirubin level significantly compared to the group that only performed exchange transfusion without infusion of albumin. ${ }^{10}$

Phototherapy is indicated in infants with hyperbilirubinemia based on total serum bilirubin and risk factors, ${ }^{11,12}$ or the increasing amount of TSB level according to age in full term infants, or body weight in preterm neonates, which is in accordance with the recommendation of the American Academy of Pediatrics (AAP) ${ }^{13}$ Changing position has been known to maximize the area exposed to light resulting the reduction of phototherapy duration. ${ }^{7}$

Our findings the decreasing amount of serum bilirubin levels before and after 24 hours of phototherapy showed a statistically no significant result between the alternating positioned group and the supine only positioned group $(\mathrm{P}=0.751)$. A randomized study in Israel on 30 aterm infants reported that total serum bilirubin level decreased significantly in infants with supine position. ${ }^{14}$

A randomized controlled trial in Iran on 50 aterm infants that reported an insignificant difference in the reduction of total serum bilirubin level between infants who received phototherapy in supine position and those who received phototherapy in changing position every 150 minutes. $^{15}$ A study of 24 hour phototherapy on 44 hyperbilirubinemia aterm infants from Okayama (Japan) reported that the reduction of TSB level between supine position and the six hourly changed position group weren't significant. ${ }^{16}$

The effectiveness of phototherapy depend on the irradiance of the light generated by the light source using blue light. ${ }^{17,18}$ The best distance to reduce levels of TSB is $10 \mathrm{~cm}$ with a decrease in total serum bilirubin levels of approximately 58 $\%$ compared with a distance of $30 \mathrm{~cm}$ with a decrease in total serum bilirubin levels of around $45 \%$ and $50 \mathrm{~cm}$ with a decrease in total serum bilirubin levels of approximately $13 \%$.,19 American Academy of Pediatrics (AAP) recommends phototherapy with a distance of 10 $\mathrm{cm}$ except by using halogen light source. ${ }^{11} \mathrm{~A}$ distance of $20 \mathrm{~cm}$ between lamps and infant was used in this study.

Phototherapy standard should provide a light irradiance of 8 to $10 \mu \mathrm{W} / \mathrm{cm}^{2} / \mathrm{nm}$. American Academy of Pediatrics (AAP) defines intensive phototherapy as a phototherapy producing a light irradiance of at least 30 to $40 \mu \mathrm{W} / \mathrm{cm}^{2} / \mathrm{nm}$ and wavelentgths covering the entire surface of the neonate's body. ${ }^{14}$

In this research we found that the change in irradiance of light before and after phototherapy, either in alternated position group or supine position group, is still in normal range which is $8.5 \mu \mathrm{W} / \mathrm{cm}^{2} / \mathrm{nm}$ and $8.4 \mu \mathrm{W} / \mathrm{cm}^{2} / \mathrm{nm}$, respectively.

Monitoring of body temperature and fluid administration was performed intensively. Breastfeeding was given every 3 hours in exclusively breastfeed infants. When the infants received intravenous fluids, the amount of fluid was increased by $10 \%$ of the total fluid demand per day. The body temperature was measured hourly. ${ }^{9}$ when the body temperature of the neonates was more $37.5^{\circ} \mathrm{C}$, the room temperature was adjusted or the neonate was moved temporarily from phototherapy unit until his or her body temperature reached $36.5^{\circ} \mathrm{C}$ to $37.5^{\circ} \mathrm{C}$.

Side effects of hyperthermia were found in both groups 6 infants in alternated position changed in 6 infants, the group in supine position include 4 infants with temperatures ranging from $37.7^{\circ} \mathrm{C}$ to $37.9^{\circ} \mathrm{C}$. Both group of infants with hyperthermia moved temporarily from the unit phototherapy until the temperature become normal. 


\section{CONCLUSION}

Decreasing TSB levels were not significant in infant between groups alternating position every 3 hours and supine position.

\section{ACKNOWLEDGEMENTS}

We would like to thank to the parents of infants with hyperbilirubinemia, as well as all those who have helped this study.

\section{REFERENCES}

[1] Sukadi A. Hiperbilirubinemia : Kosim MS, Yunanto A, Dewi R, Sarosa GI, Usman A, editor. neonatologi. Textbook of pediatric. $1^{\text {St }}$ ed. Jakarta: Ikatan Dokter Anak Indonesia, 2008. p. 147-69

[2] Stoll BJ, Kliegman RM. Jaundice and hyperbilirubinemia in the newborn: Behrman RE, Kliegman RM, Jenson HB, editor. Nelson textbook of pediatrics. $18^{\text {th }}$ ed. Philadelphia: Saunders Elsevier, 2006. p.754-66

[3] Lissauer T, Fanarrof A. Icterus. At a glance neonatology. Erlangga medical series, Neonatology at a glance, 2006. p.96-9

[4] Gomella TL. Hyperbilirubinemia, indirect: Gomella TL, editor. Neonatology: management, procedures, on-call problems, diseases, and drugs. $6^{\text {th }}$ ed. New York: The McGraw-Hill Companies, Inc; 2009. p.293-301

[5] Tokowski LA. Fundamentals of phototherapy for neonatal jaundice. J Adv Neotal Care. 2006; 6:303-12

[6] Maisels MJ, Mc Donagh AF. Phototherapy for neonatal jaundice. N Engl J Med. 2008; 358- 8

[7] Donnebord ML, Knudsen KB, Ebbesen F. Effect of infant's position on serum bilirubin level during conventional phototherapy. J Acta Pediatr. 2010; 99:1131- 4

[8] Lauer BJ, Spector ND. Hyperbilirubinemia in the newborn. J Pediatr. 2011; 32-341

[9] Subcommittee on Hyperbilirubinemia, American Academy Of Pediatrics. Management of hyperbilirubinemia in the newborn infant 35 or more weeks of gestation. Pediatrics. 2004; 114:297-316
[10] Shahian M, Moslehi MA. Effect of albumin administration prior to exchange transfusion in term neonates with hyperbilirubinemia-a randomized controlled trial. J Indian Pediatr. 2010; 47:241-44

[11] Ip S, Chung M, Kulig J, O’brien R, Sege R, Glicken S. An evidence- based review of important issues concerning neonatal hyperbilirubinemia. J Pediatr. 2004; 114-30

[12] Bhutani VK, Stark AR, Lazzeroni LC, Poland R, Gourley GR, Kazmierczak S. et all. Predischarge screening for severe neonatal hyperbilirubinemia identifies infants who need phototherapy. J Pediatr. 2013; 162:477-82

[13] Bhutani VK And Committee on fetus and newborn. Phototherapy to prevent severe neonatal hyperbilirubinemia in the newborn infant 35 or more weeks of gestation. Pediatrics. 2011; 128:1046-52

[14] Shinwell ES, Sciaky Y, Karplus M. Effect of position changing on bilirubin levels during phototherapy. J Perinatol. 2002; 22:226-9

[15] Muhammad A, Bostani Z, Jafarnejad F, Mazloom R. Supine versus turning position on bilirubin level during phototherapy in health term jaundice neonates. Saudi Med J. 2004; 25:2051-2

[16] Yamauchi Y, Kasa N, Y manouch I. Is it necessary to change the babie's position during phototherapy?. Early Human Dev. 1989; 20:221-7

[17] Seidman DS, Moise J. Ergaz Z, Laor A, Vreman HJ, Stevenson DK. A new blue lightemitting phototherapy device: A prospective randomized controlled study. J Pediatr. 2000; 136:771-4

[18] Kumar P, Murki S, Malik GK, Chawla D, Deorari AK, Karthi N. At all. Light-emitting diodes versus compact fluorescent tubes for phototherapy in neonatal jaundice: a multiplecenter randomized controlled trial. Indian Pediatr. 2010; 47:131-7

[19] Vreman HJ, Wong RJ, Stevenson DK. Phototherapy: Current methods and future directions. Semin Perinatol. 2004; 28:326-33

Citation: Ira Silvia, Guslihan Dasa Tjipta, Lily Irsa, Emil Azlin, Bugis Mardina Lubis, Oke Rina Ramayani. Changes on Total Serum Bilirubin and Infant's Position during Phototherapy. ARC Journal of Pediatrics. 2018; 4(1): 9-13. doi:dx.doi.org/10.20431/2455-5711.0401002.

Copyright: (1) 2018 Authors. This is an open-access article distributed under the terms of the Creative Commons Attribution License, which permits unrestricted use, distribution, and reproduction in any medium, provided the original author and source are credited. 